\title{
Article \\ Economic analysis of P.monodon post larvae by-catch in Indian Sundarbans: An impasse between livelihood and conservation
}

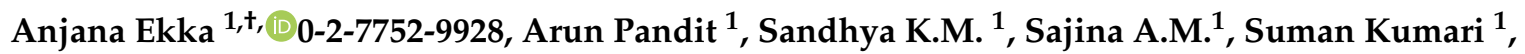 \\ D.K. Biswas ${ }^{1}$ and B.K.Das ${ }^{1}$ \\ 1 ICAR-Central Inland Fisheries Research Institute, India \\ * Correspondence: aekka@tudelft.nl \\ + Current address: Water Resources Section, Faculty of Civil Engineering and Geosciences, Delft University of \\ Technology, The Netherlands
}

\begin{abstract}
The livelihood of most of the fishers in Indian Sundarbans is dependent on Penaeus monodon post larvae fishing. These post larvae collectors are socially backward lacking economic security. The activity of collecting Penaeus monodon post larvae for rearing in aquaculture, destroy other aquatic species. Many other juveniles of shellfish and fin fish were destroyed in the process of collection of Penaeus monodon post larvae. The removal of juveniles before they reach maturity disturbs the ecological chain by hampering breeding processes and may cause extinction of some fish species in the long run. The present study is an attempt to estimate the economic value of juveniles destroyed in the collection of (Penaeus monodon) post larvae. In total 32 species were identified in P.monodon the post larval by-catch. The economic loss is assessed based on estimating biomass by taking a length-weight relationship from published literature. Further, the paper illustrates how does a profit enterprise is linked with natural resource exploitation. The paper explores government policy and nature conservation issues for social justice and effective conservation.In conclusion, suggestions are given to reduce the burden of livelihood on natural resources to the extent of exploitation and to strengthen institution and policy-making considering socio-ecological vulnerabilities of the area.
\end{abstract}

Keywords: Economic analysis; conservation; P.monodon; by-catch; livelihood; seed collector, Post larvae collector; coastal aquaculture; Indian Sundarbans

\section{Introduction}

The Sundarban Biosphere Reserve is the world's largest mangrove forest and the delta of Ganga-Brahmaputra and Meghna, shared between India (40 percent) and Bangladesh (60 percent).The Sundarban estuary is considered as goldmine of fishes [1]. The unique mangrove vegetation plays an important role in providing ideal nursery and breeding grounds to number of estuarine shell fish and fin fish [1-3].Around 95 percent of the population is directly or indirectly dependent on Sundarban ecosystem for their livelihood and take up occupations like agriculture, aquaculture and fisheries. [4].

Certain livelihood activities become a major threat to ecosystem resilence such as Penaeus monodon post larvae collection from the rivers and creeks in the Sundarbans as it affects the ecological balance of the The shrimp farming ${ }^{1}$ in Indian Sundarbans started in the 6th five-year plan (1980-1985) to develop

1 The shrimp farming refers to the culture of varieties of shrimp like Penaeus monodon and L.Vannamei but in the paper shrimp is referred to Penaeus monodon species 
coastal aquaculture with the assistance of the World Bank and other development agencies[5,6]. Due to high market rate in the international market, the culture of shrimp farming more specifically Penaeus monodon gained momentum, and the demand of Penaeus monodon fry increased many folds as more and more area brought under intensive Penaeus monodon culture. The major constraints in shrimp farming were the availability of good quality seeds. Most of the shrimp farmers prefer wild caught fry of shrimps due to low mortality rate. The expanding interest for the P.monodon seed by mushrooming fish farm along the shorelines of Sundarbans allured poor coastal fishers into the prawn seed business to earn livelihood [7]. The Hugli-Malta estuarine complex provides a unique and most productive nursery grounds for many shellfish and fin-fish in Indian Sundarbans[8]. Many people are engaged in collecting post larvae of P.monodon and it has become a source of livelihood for many households in coastal regions of Indian Sundarbans[8,9].During Penaeus monodon post larvae collection, many other juveniles of other shellfish and fin-fish were destroyed $[1,8,10]$.Fishing nets of very small mesh size are used which capture all sizes of fishes including the non-targeted species. The non-targeted species are discarded in high quantity or dried and sold at cheaper price to fish meal industries.The removal of juveniles before they attain maturity could negatively impact fish diversity and have the possibility to destabilize the fisheries potential in the future [11]. From last three decade, many researchers $[9,10,12-14]$ have attempted to document the quantitative assessment and description of non-targeted species found in by-catch but none of the studies gave a glimpse of the economic loss of by-catch in targeted species.

Here, we present a case study of Indian Sundarbans where the shrimp farming has given rise to social and ecological issues impacting the social and ecological integrity of the mangrove ecosystem. Therefore, the objective of the paper is to estimate the quantitative loss of by-catch in monetary terms. Further, the study exemplifies how human activities create environmental problems and creates impasse between livelihood and conservation. The paper is organized into three principal parts. In the first part, we discuss the different aspects of socio-ecological system like institutional policy and government intervention, including demographic distribution contributing to take up vulnerable occupation like prawn seed collection (section 2). The second part focuses on methodology to estimate the biomass of juveniles at first maturity based on length-weight relationship and finally estimating the economic value based on market price (section 3 and 4). The third part discuss about the impasse between livelihood and conservation issues and touches various issues of interconnection among profit enterprise, livelihood and environemental conservation. This paper will therefore provide an socio-economic view point of conservation and government policies which will help to strengthen institution and policy making in future.

\section{Fishing and livelihood in Indian Sundarbans}

The Sundarbans mangroves are considered a unique ecosystem habitat [15,16].It has been formed by alluvial deposits carried by several rivers in the delta of the Ganga-Brahmaputra and Meghna shared between India and Bangladesh at the mouth of Bay of Bengal [17]. From a geological aspect, the formation of Sundarbans is of recent origin around 12th to 15th century A.D [18,19].The tectonic activity changed the sedimentation process which influences the hydrology of the newly formed deltaic region. The rapid sediment formation leads to the emergence of new landmass, and mangrove vegetation accelerated the progradation of delta[20]. Ecologically, Sundarbans is a rich biodiversity hotspot for flora and fauna. The sole habitat for endangered species like Royal Bengal Tiger and saltwater crocodile [16]. The mangrove swamps also provide ambient breeding grounds and shelter for juvenile fishes and other aquatic organisms [21,22]. The swampy mangrove marshes protect embankments from tidal surges and storms [23]. Land Reclamation for farmlands and human settlements of the Indian part of the Sundarban started in early 1770 [24]. The main movement of the human population in Sundarbans occurred in the 19th century due to migration from adjacent districts of Bengal as well as refugees from East Pakistan (presently known as Bangladesh) [25]. According to 
Danda et al. 26, human settlements are found in 54 deltaic islands in Indian part of Sundarbans.

Before Independence, during the colonial era, around 1500 sq. $\mathrm{km}$ of forest were lost due to the clearance of forests for cultivated lands.The fragmentation of landholdings through the generation and harsh climatic conditions in the form of cyclonic events and brackish floodwater makes that area unfit for agricultural cultivation. The majority of population tends to depend on natural resources for their livelihood support. Moreover,fishing plays a vital role in providing livelihood.

After independence, the population of Indian Sundarbans grew from 1.15 million in 1951 to 4.44 million in 2011 [27]. In the year 1973, the Government of India created Sundarban Tiger Reserve, and subsequently the creation of different protected zones prohibited fishing in buffer and core area (Table 1), which is the only source of survival for local inhabitants, which ultimately leads to deprived livelihood. It gave rise to conflict between environmental protection needs and local fishermen [28-30]. Moreover, large and mechanized boats operating in Sundarbans are threatening the livelihood of small scale-fishers[26]. Besides, women and children are hitting local creeks and canals for shrimp seeds and crabs, which make them more vulnerable to adverse conditions. According to Das and Jana [31],prawn seed and crab collectors were worst affected by saltwater crocodile exposing them to life-threatening surroundings.

Table 1. Legal and Institutional overview of Indian Sundarbans

\begin{tabular}{|c|c|c|c|}
\hline Legal designation & Year & Area (sq.km) & Activities prohibited/regulated \\
\hline Sundarban Tiger Reserve (STR) & 1973 & 2585 & $\begin{array}{l}\text { Divided into two parts (Core and buffer). } \\
\text { The core area is prohibited } \\
\text { from human interference }\end{array}$ \\
\hline Sajnakhali Wildlife Sanctuary & 1976 & 362.40 & $\begin{array}{l}\text { It is a part of the buffer area of the STR. } \\
\text { Anthropogenic activities like fishing } \\
\text { and hunting are prohibited }\end{array}$ \\
\hline Lothian Wildlife Sanctuary & 1976 & 38 & $\begin{array}{l}\text { It forms a part of the buffer area of the STR. } \\
\text { Fishing and hunting activities are prohibited }\end{array}$ \\
\hline Haliday Wildlife Sanctuary & 1976 & 6 & Forms a part of Sundarban Bio Reserve \\
\hline Sundarbans National Park & 1984 & 1330 & $\begin{array}{l}\text { It forms a part of the buffer area of the STR. } \\
\text { Fishing and hunting activities are prohibited }\end{array}$ \\
\hline Sundarbans Biosphere Reserve & 1989 & 9630 & $\begin{array}{l}\text { It is divided into } 3 \text { parts; } \\
\text { Core Area, Buffer Area, and transition Zone }\end{array}$ \\
\hline Critical Tiger habitat & 2007 & 1699.62 & $\begin{array}{l}\text { It is a part of STR where all } \\
\text { anthropogenic activities are banned }\end{array}$ \\
\hline
\end{tabular}

Source : Compiled from Patel and Rajagopalan [32] and Chacraverti [33]

\section{Methodology}

The methodology is discussed in the following heads

\subsection{Collection of fish samples}

The P.monodon larvae are generally found in abundant in creeks and estuaries. Also, tidal pools and inundated pits are considered as excellent breeding ground for juveniles of fin fishes[34]. In estuaries, juveniles of shell and fish are found in abundant during full moon and new moon periods $([34,35]$. All the estuaries showed a similar trend of the rising graph of abundance both during Full moon and New moon periods. The sampling site is situated in Bakkhali region of Indian Sundarbans in Hatania Doania river(Figure 1). A river of $2 \mathrm{~km}$ stretch is taken for the study (N 2137.182 ' and E 08800.000 '). The fishing area of each zone is divided based on villages. The sampled river stretch covered around 200 fishers. 


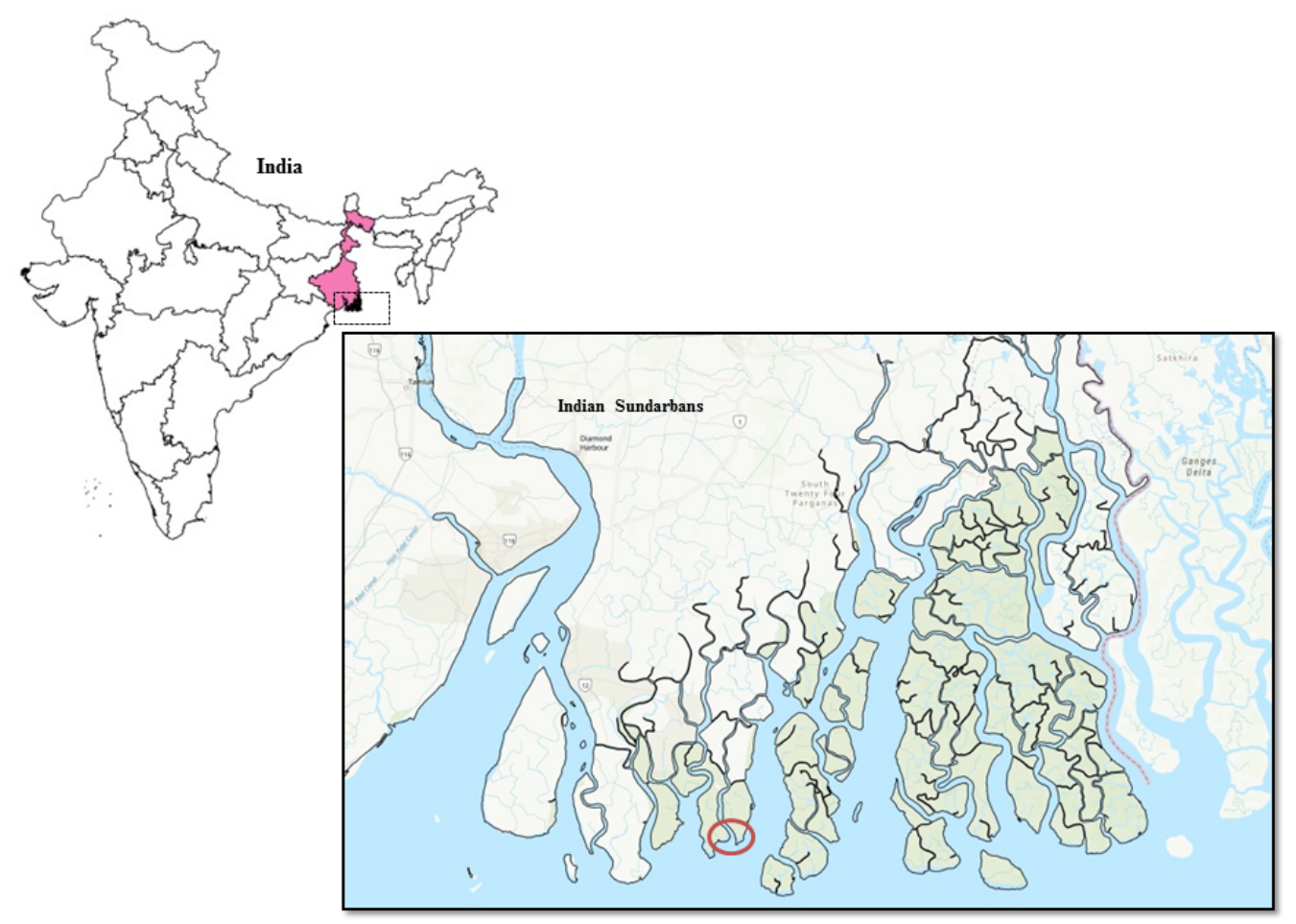

Figure 1. Map of the study area

During this period the P.monodon post larvae collection activity is maximum since, the juveniles come on surface due to high tides. Shootings nets were used for collection of samples. The size of the net was diameter $25 \mathrm{~m}$, length $26 \mathrm{~m}$. It is a long funnel shaped net tied at the tail end of the shoot net and set against tidal water to filter seed from the estuarine water (See Figure 2). Before onset of high tide, the boat is taken to midstream and anchored. One or two shoot nets are tied with the boat using big plastic drums floating in the water. At the onset of the tide, the net mouths are kept open and fully extended with the help of bamboo to allow as much as water to flow inside the net. The nets are lifted at an interval of 30-40 minutes, and the whole content is emptied in an aluminum container. The net is lifted and adjusted automatically to the rise in water level. After the segregation is over, the leftover fin fish and shell fishes were dumped or left in due course of time. Samples were collected from 2 nets belonging to commercial P.monodon post larvae collectors at the sampling site. When the catch was low, the entire sample is taken, but when the catch was high, a suitable sub sample was analyzed, and the total number was obtained by increasing samples proportionately (figure 3). Samples collected were then segregated according to species or group. Most of the species were identified at field level. Apart from taxonomical identification, some fish species were identified based on their local names. Length and weight of 10 samples of individual species were taken and genera wise aggregate weights of fish were recorded. Unidentified fish species or fish species having some doubt during field level identification were preserved in 5 percent formalin and labelled adequately for laboratory analysis. 


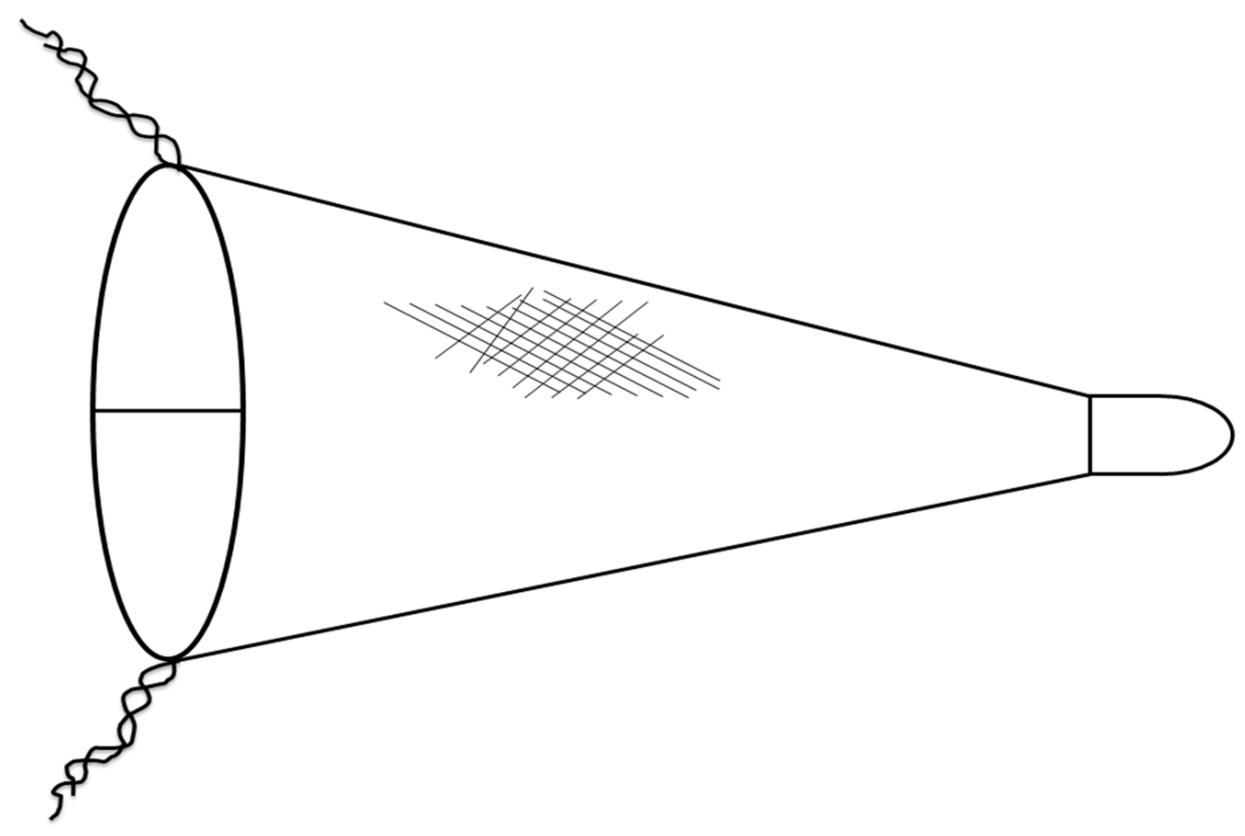

Figure 2. Funnel shaped shooting net used for the collection of P.monodon post larvae

\subsection{Data collection from P.monodon post larvae collectors}

洒

The socio-economic data of P.monodon post larvae collectors were collected from the household who are actively involved in the post larvae collection business.It comprises of queries regarding the perception of P.monodon post larvae collectors towards P.monodon the collection activity including expenses and profit involved in operating boat for post larvae collection. Since, the collection of post larvae is directly linked with shrimp farming business; therefore complete data on marketing channel from post larvae collectors to shrimp farm were also collected to understand the complete marketing link of shrimp business. 


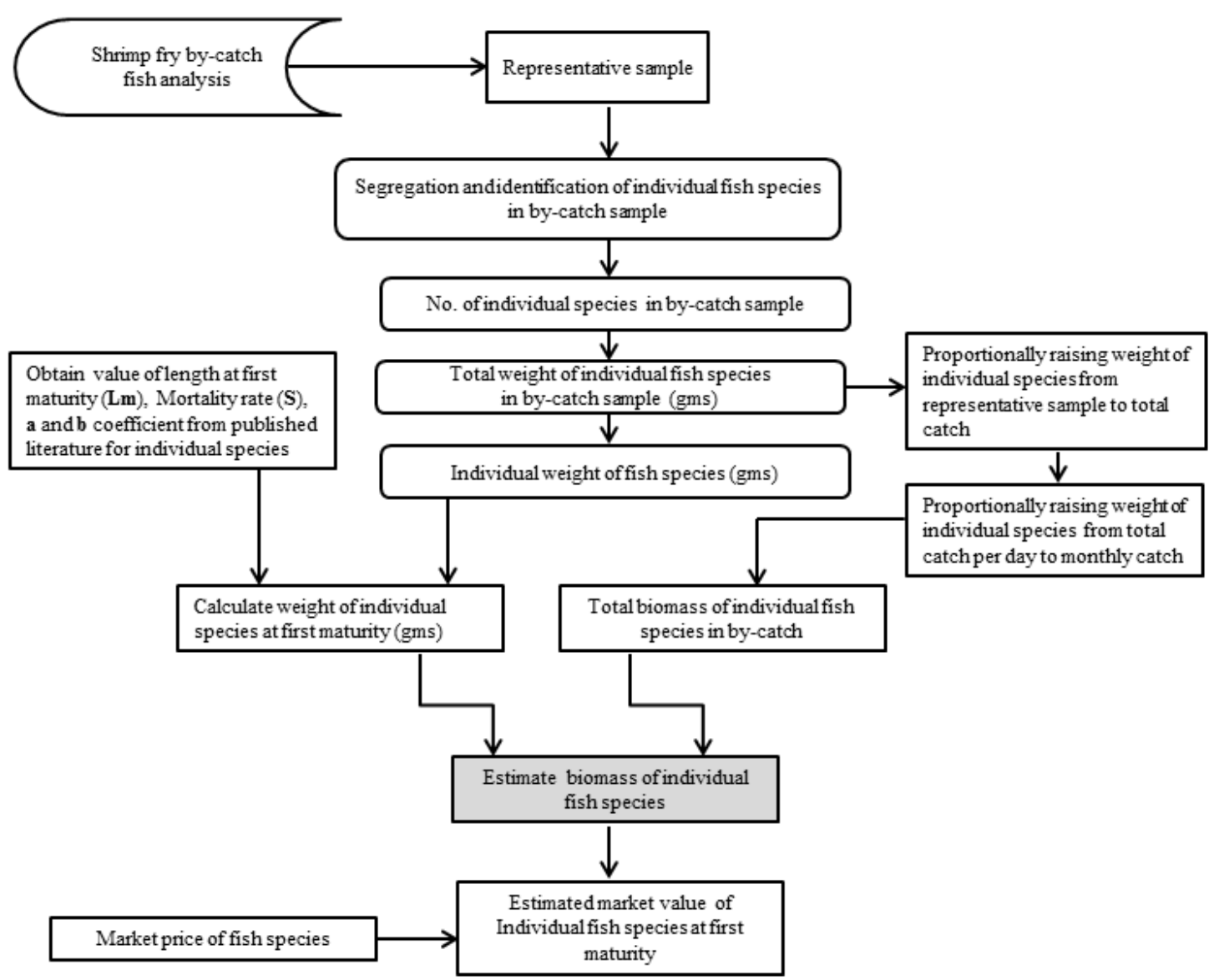

Figure 3. Methodology

\subsection{Analytical Techniques}

The methodology for calculating biomass is based on the assumption that if the juveniles are left to grow up to a certain period and were caught later after attaining maturity (known as weight at first maturity) how much it will cost. It is also based on the assumption that biomass of juveniles increase will increase positively with their growth rate and negatively with their mortality rates[36]

$$
W=a L^{b}
$$

where, $\mathrm{W}$ is the estimated weight (gms) of $\mathrm{i}^{\text {th }}$ fish species at first maturity, $\mathrm{a}$ is constant value $\mathrm{and} \mathrm{b}$ is length $(\mathrm{cm})$ at maturity of $\mathrm{i}^{\text {th }}$ species. The average sample () was calculated by FAO, 1984

$$
\bar{Y}=\sum_{i=1}^{n} Y_{\mathrm{ij}} / n
$$

where, $\mathrm{Y}_{\mathrm{ij}}$ is the total catch of $\mathrm{i}^{\text {th }}$ species, and $\mathrm{n}$ is no. of sampling per day

In certain month, the quantity of catch is much higher, and it is not possible to count and calculate the whole catch. Therefore a representative sample was taken, and the proportion of each species 
was calculated in the sample. The proportion of each species in total catch was calculated using the following formula:

$$
\frac{w_{\mathrm{i}} / s s_{\mathrm{i}}}{w s_{\mathrm{i}}} \times W T_{\mathrm{i}}
$$

$\mathrm{w}_{i}=$ individual weight of $\mathrm{i}^{\text {th }}$ species in representative sample $\mathrm{ss}_{i}=$ no. of $\mathrm{i}^{\text {th }}$ species in the representative sample $\mathrm{ws}_{i}=$ total weight of representative sample $\mathrm{WT} T_{i}=$ total weight of the catch

The quantity of biomass corresponding to juveniles was calculated to juveniles landed by the following formula:

$$
Q_{\mathrm{A}}=S \times \frac{W_{i}}{w_{i}}
$$

$\mathrm{Q}_{\mathrm{A}}=$ Estimated quantity of biomass of Juveniles, $\mathrm{W}_{i}=$ weight of $i$ species at first maturity (in gms), $\mathrm{w}_{i}=$ weight of juveniles of $i$ species (in gms), $\mathrm{S}=$ Survival rate of $i$ species

The survival rate, S, was estimated by modifyingRicker [37] method as,

$$
S=\exp ^{-M}
$$

where $\mathrm{M}=$ natural mortality coefficient.

$\mathrm{Z}$, the total mortality coefficient, was replaced by $\mathrm{M}$ in the equation as the condition assumed for estimating the economic loss by fishing was the mortality in the population was only due to natural causes, i.e. $\mathrm{Z}=\mathrm{M}$.

M for individual species was calculated by [36] based on asymptotic length (L), growth coefficient (K). L and $\mathrm{K}$ values were obtained from growth studies in the same habitat area and also from similar ecosystems taken from secondary literature.

\section{Results}

The results are discussed in the following heads

\subsection{Species composition in by-catch}

Both taxonomical and field level identification tools were used to identify species.Total 32 species belonging to 24 families have been identified from post larvae by-catch (Table 2). Fish species like Escualosa thoracata, Liza sp, Acetes indicus, Scylla serrata are reported every month during whole sampling period. Juveniles of Tenualosa ilisha,Anodontostoma chacunda, Setipinna phasa, Nandus nandus, Coilia dussumieri, Photopectoralis bindus, Otolithoides pama, Periophthalmus sp, Glossogobious giuris, Pseudapocryptes elongatus and Eleotris senegalensis were found only once during the whole sampling period. Three to four species was recorded from the Clupeidae, Engraulidae, Gobiidae, Penaeidae family. On an average, 11-15 species were recorded every month. In the month of August 22 species were recorded. 
Table 2. Juveniles of fishes identified in the by-catch of P.monodon post larvae by-catch

\begin{tabular}{|c|c|c|c|c|c|c|c|c|c|}
\hline Group & Family & Species & March & April & May & June & July & August & September \\
\hline \multirow{4}{*}{ Clupeids } & \multirow{4}{*}{ Clupeidae } & Tenualosa ilisha & & & & & & ++ & \\
\hline & & Gudusia chapra & & & & ++ & ++ & ++ & ++ \\
\hline & & Anodontostoma chacunda & & ++ & & & & & \\
\hline & & Escualosa thoracata & ++ & ++ & ++ & ++ & ++ & ++ & ++ \\
\hline \multirow{3}{*}{ Anchovies } & \multirow{3}{*}{ Engraulidae } & Stolephorus commersonii & ++ & & & ++ & ++ & & \\
\hline & & Coilia dussumieri & & & & & ++ & & \\
\hline & & Setipinna phasa & & ++ & & & & & \\
\hline \multirow{5}{*}{ Perch like fishes } & Serranidae & Epinephelus diacanthus & ++ & & & & & & \\
\hline & Carangidae & Parastromateus niger & ++ & ++ & ++ & & & & \\
\hline & Scatophagidae & Scatophagus argus & ++ & ++ & & ++ & & & \\
\hline & Nandidae & Nandus nandus & & ++ & & & & & \\
\hline & Terapontidae & Terapon jarbua & & & & & & ++ & ++ \\
\hline \multirow{2}{*}{ Threadfins } & \multirow{2}{*}{ Polynemidae } & Eleutheronema tetradactylum & & & & ++ & & ++ & \\
\hline & & Polynemus paradiseus & & & & & ++ & ++ & ++ \\
\hline Pony fishes & Leiognathidae & Photopectoralis bindus & & & & & ++ & & \\
\hline Croakers & Sciaenidae & Otolithoides pama & & & & & & ++ & \\
\hline Lizardfishes & Synodontidae & Harpadon nehereus & & & ++ & & ++ & ++ & ++ \\
\hline Mullets & Mugilidae & Liza sp & ++ & ++ & ++ & ++ & & ++ & \\
\hline \multirow{4}{*}{ Gobids } & \multirow{4}{*}{ Gobiidae } & Periophthalmus sp & & ++ & & & & & \\
\hline & & Glossogobious giuris & & ++ & & & & & \\
\hline & & Pseudapocryptes elongatus & & & & & & ++ & \\
\hline & & Odontamblyopus rubicundus & & ++ & ++ & & & & \\
\hline \multirow{2}{*}{ Flatheads } & Platycephalidae & Platycephalus indicus & ++ & ++ & & ++ & & ++ & \\
\hline & Eleotridae & Eleotris senegalensis & & & ++ & & & & \\
\hline Ribbon fishes & Trichiuridae & Lepturacanthus savala & ++ & ++ & ++ & ++ & ++ & ++ & \\
\hline Flatfishes & Cynoglossidae & Cynoglossus sp & ++ & & & & & & ++ \\
\hline Cyprinids & Cobitidae & Lepidocephalus guntea & & & & & & ++ & ++ \\
\hline Catfishes & Bagridae & Mystus gulio & ++ & & ++ & ++ & & ++ & ++ \\
\hline \multirow{4}{*}{ Penaeid prawns } & \multirow{4}{*}{ Penaeidae } & Fenneropenaeus indicus & & & & ++ & & ++ & \\
\hline & & Metapenaeus monoceros & ++ & & ++ & & & & \\
\hline & & Metapenaeus brevicornis & & ++ & ++ & ++ & & ++ & \\
\hline & & Parapenaeopsis sculptilis & & & & & ++ & ++ & \\
\hline \multirow{3}{*}{ Nonpenaeid prawns } & \multirow{2}{*}{ Palaemonidae } & Macrobrachium malcolmsonii & ++ & & & & & ++ & \\
\hline & & Exopalaemon styliferus & & ++ & & & ++ & & \\
\hline & Sergestidae & Acetes indicus & ++ & ++ & ++ & ++ & & ++ & ++ \\
\hline
\end{tabular}




\subsection{Biomass loss of fish species}

The monthly wise loss of juveniles due to P.monodon by-catch is given in figure 4 . The maximum loss is recorded in the month of July with $115 \mathrm{~kg}$ per day and minimum loss of $2.64 \mathrm{~kg}$ is recorded in March. The lean period is observed from the month of October to February. The biomass estimated for the discarded juveniles as by-catch during P.monodon post larvae collection is given in Table 3. The estimated biomass is completely based on the juveniles' fish/ discarded fish quantity landed and the mortality rate and weight of fish at first maturity. The highest quantity is estimated for Acetes species (25.54 percent) in the total quantity followed by Esculanta thoracata (16.73 percent, Stoloferous commersonii (12.98 percent) and Therapon Jharbua (10.83 percent). The fecundity rate of these fish species are high, therefore the juveniles are found in large quantity in the total catch. The minimum quantity of by-catch is recorded for fish species like Setipinna phasa, Nandus nandus species.

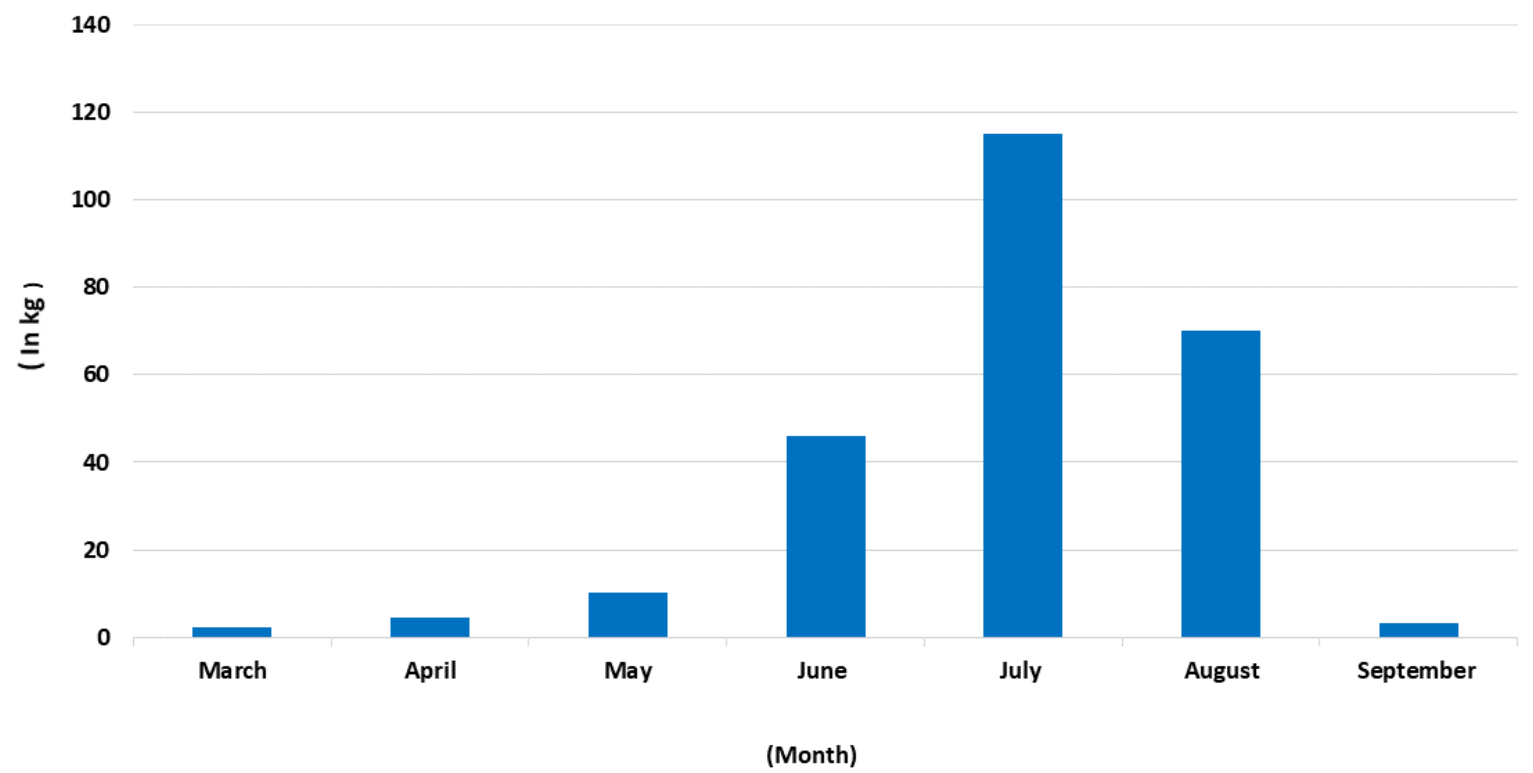

Figure 4. Monthly biomass loss of fish species in by-catch

\subsection{Economic analysis of by-catch loss}

The economic analysis of P.monodon by-catch completely relied on the quantity of by-catch discarded, the composition of fish species in the by-catch, estimated biomass of fish species, and landing price of individual fish species. The economic value of species wise by-catch and estimated value at first maturity is indicated in figure 5. The estimated economic value depends on 2 factors, i.e. Biomass calculated and price of the fish. Minimum landing price is taken to get the exact environmental cost associated with P.monodon post larvae collection activity without the addition of other costs of production as used in the analysis. The highest value was recorded for fish species like Therapon jharbua,Liza sp, Elutheronema tetradactylum, Platycephalus indicus, Lepturacanthus savala. The negative value is estimated for fishes which includes Acetes sp, Cynoglossus sp, Lepidocephalus guntea, Peripthalamus species, Glosogobius girius, Nandus nandus. Since these species have high fecund rate,its juvenile fetches more price in the market compared to market price when sold at first maturity. 
Table 3. Comparison of biomass of by-catch and estimated biomass after attaining maturity

\begin{tabular}{|c|c|c|c|}
\hline Species & $\begin{array}{l}\text { Weight of by-catch } \\
\text { (in } 1000^{\prime} \mathrm{kg} \text { ) }\end{array}$ & $\begin{array}{l}\text { Estimated biomass } \\
\text { (in } 1000^{\prime} \mathrm{kg} \text { ) }\end{array}$ & Change in by-catch-adult biomass ratio ) \\
\hline Tenualosa ilisha & 16.62 & 309.49 & 0.05 \\
\hline Gudusia chapra & 389.56 & 96.09 & 0.45 \\
\hline Anodontostoma chacunda & 1.18 & 0.00 & 456.06 \\
\hline Escualosa thoracata & 2529.22 & 465.31 & 5.44 \\
\hline Stolephorus commersonii & 1585.67 & 1006.39 & 1.58 \\
\hline Coilia dussumieri & 13.78 & 162.23 & 0.08 \\
\hline Setipinna phasa & 0.67 & 0.01 & -64.76 \\
\hline Epinephelus diacanthus & 1.59 & 0.10 & 16.18 \\
\hline Parastromateus niger & 5.73 & 0.06 & 88.98 \\
\hline Scatophagus argus & 6.70 & 0.09 & 75.78 \\
\hline Nandus nandus & 0.44 & 0.00 & 12990.44 \\
\hline Terapon jarbua & 1065.31 & 2331.87 & 0.46 \\
\hline Eleutheronema tetradactylum & 108.04 & 1565.56 & 0.07 \\
\hline Polynemus paradiseus & 1007.63 & 634.47 & 1.59 \\
\hline Photopectoralis bindus & 248.13 & 306.64 & 0.81 \\
\hline Otolithoides pama & 24.94 & 72.13 & 0.35 \\
\hline Harpadon nehereus & 749.29 & 2725.97 & 0.27 \\
\hline Liza $s p$ & 96.27 & 709.65 & 0.14 \\
\hline Periophthalmus sp & 0.74 & 0.00 & 38539.07 \\
\hline Glossogobious giuris & 1.85 & 0.00 & 8484.70 \\
\hline Pseudapocryptes elongatus & 274.29 & 1015.32 & 0.27 \\
\hline Odontamblyopus rubicundus & 2.57 & 0.00 & 28473.26 \\
\hline Platycephalus indicus & 35.87 & 3213.83 & 0.01 \\
\hline Eleotris senegalensis & 0.87 & 0.00 & 872.32 \\
\hline Lepturacanthus savala & 1625.60 & 2542.18 & 0.64 \\
\hline Cynoglossus sp & 678.45 & 59.33 & 11.44 \\
\hline Lepidocephalus guntea & 52.23 & 5.32 & 9.83 \\
\hline Mystus gulio & 549.09 & 219.75 & 2.50 \\
\hline Fenneropenaeus indicus & 107.36 & 20.34 & 5.28 \\
\hline Metapenaeus monoceros & 1.99 & 0.00 & 1502.20 \\
\hline Metapenaeus brevicornis & 76.32 & 5.83 & 13.10 \\
\hline Acetes indicus & 3785.72 & 23.71 & 159.65 \\
\hline
\end{tabular}




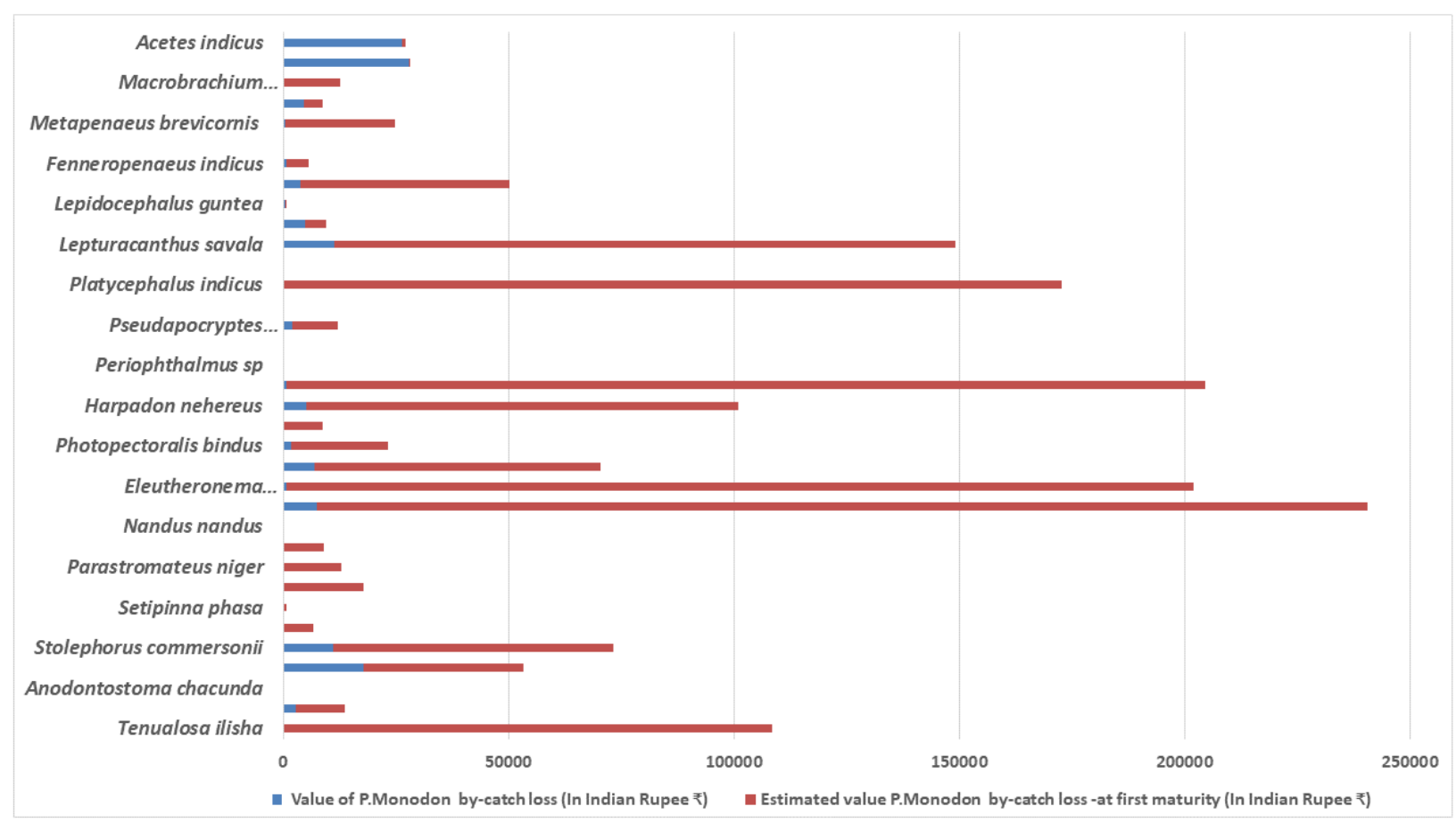

Figure 5. Comparison of economic value of fish species in by-catch and estimated value at first maturity

\subsection{Market chain analysis of P.monodon larvae trade}

The market chain from P.monodon collector to shrimp farmers passes through several intermediaries. Through the primary survey, a total number of 4 intermediaries were identified in the whole marketing channel of shrimp post-larvae trade(Figure 6). The demand for shrimp post larvae is high in shrimp farming, but supply is limited, and therefore a strong network has been developed with shrimp seed collectors and traders. The market intermediates links shed light on a tight business tied up for a very fragile commodity being transported so quickly to the shrimp farms. The fry caught by fishermen is first collected by the middleman in the coastal area. The collected larvae from the coastal regions is then transported by small van to the shrimp farming area at the Kathi centre known as seed collection bank. Then it was transported to the shrimp seed traders located in shrimp farming areas. At this stage, the seed is kept in small nursery ponds and reared to fry or fingerling stage and sold to the shrimp farmers. 


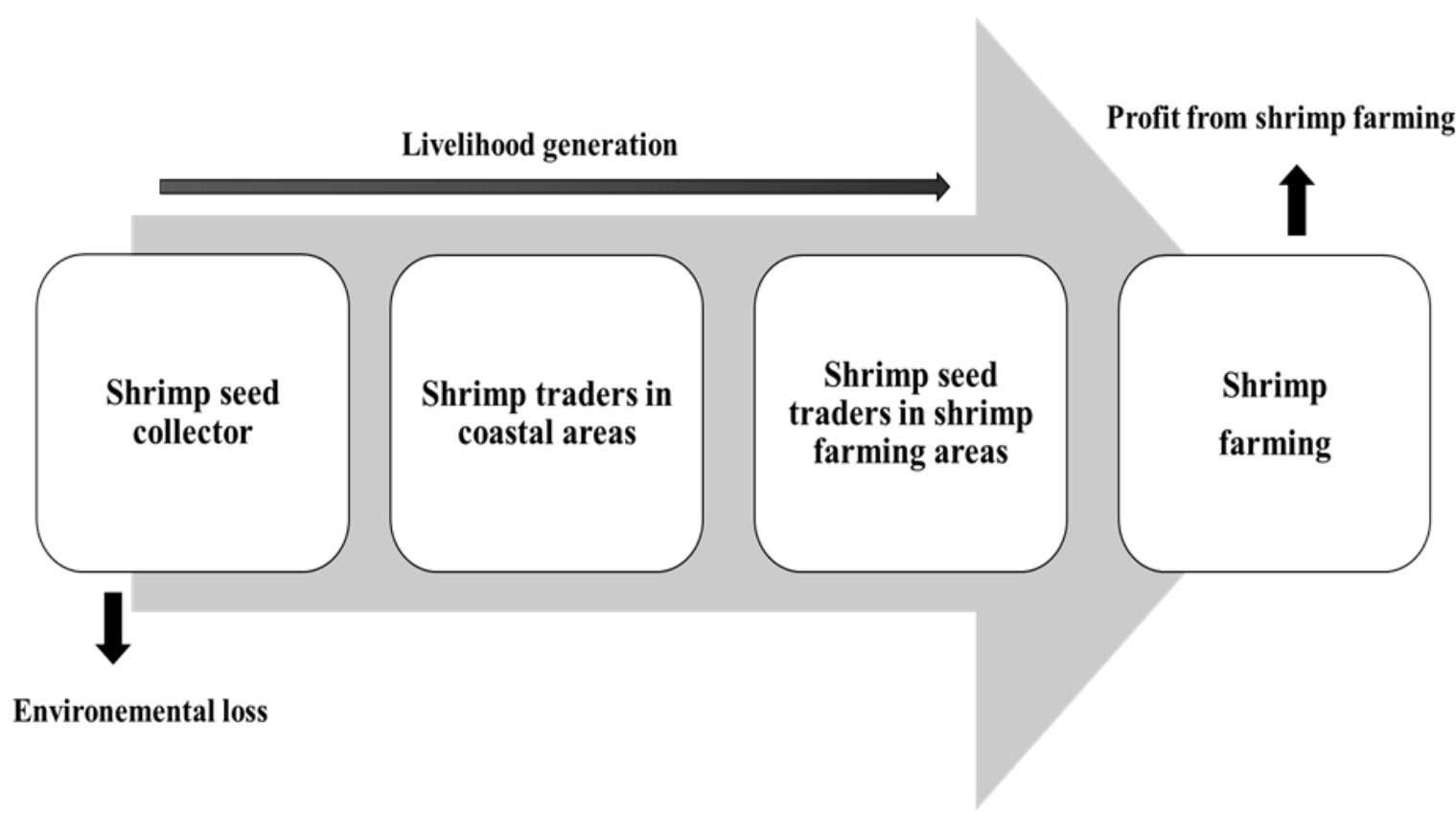

Figure 6. Marketing chain of shrimp post larvae trade

The cost-benefit analysis of market chain trade is estimated based on information collected during the primary survey on each stage of market chain trade. The cost-benefit analysis of fishers involved in fishing is first estimated based on their expenditure on the fixed and variable cost of fishing. The fixed cost variable includes depreciation cost on boat and nets. The variable cost includes daily labour cost, cost of diesel and repair and maintenance cost of craft and gears. The price is taken for the year 2015 and the inflation rate was applied to summate with the year 2019. The benefit-cost ratio at this stage is estimated to be 1.33 . The cost-benefit ratio for middleman 1 and middleman 2 is estimated to be around 1.61 and 1.69 respectively. The P.monodon larvae collector earns the least as they invest more in fishing infrastructures like gears and boat. which decreases the profit. The investment of other intermediaries is less compared to P.monodon larvae collector which resulted in the high benefit-cost ratio. In addition, the economic and social cost of Shrimp farming is calculated based on per hectare profit from shrimp farming (Figure 7) It is assumed that 10,000 P.monodon larvae (stocking density) is required for semi-intensive farming per ha. The profit from shrimp farming negatively impact the environment by loss of juveniles. It also creates livelihood opportunities to people in coastal sundarbans thereby providing economic security to some extent. the ecological cost is more compared to the profit from shrimp farming and livelihood generation. 
Table 4. Economic analysis of market chain intermediaries

\begin{tabular}{llll}
\hline Market chain intermediaries & $\begin{array}{l}\text { Cost price } \\
\text { (In Rs) }\end{array}$ & $\begin{array}{l}\text { Revenue earned } \\
\text { (in Rs) }\end{array}$ & Benefit-cost ratio \\
\hline Seed collector & 65495.19 & 86932.33 & 1.33 \\
Middleman 1 & 224856.94 & 362892.94 & 1.61 \\
Middleman 2 & 246418.52 & 416783.73 & 1.69 \\
Middle man 3 & 1348227.53 & 2657561.56 & 1.97 \\
\hline
\end{tabular}

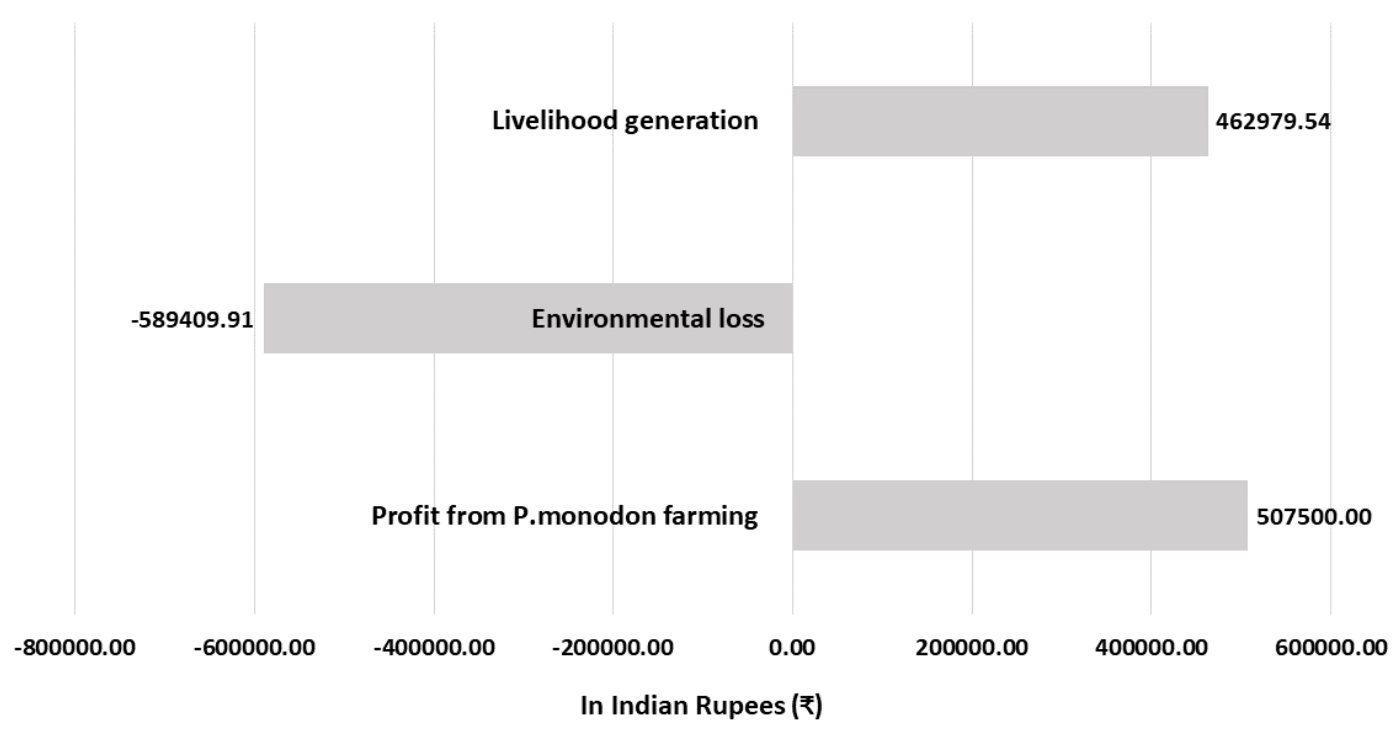

Figure 7. The economic, social and environmental cost of P.monodon farming

\section{Discussion}

Fisheries is a good indicator of the biophysical, ecological, and social integrity of riverine socio-ecological system[38].The paper attempts to explore the complexities of socio-ecological system by addressing the issue of seed collectors and the extent of damage of juveniles in economic terms of other fin fishes during P.Monodon larvae collection. The results depicts that price plays an important role in the determination of value of fishes.

The loss of juveniles due to post larvae collection is a matter of concern for sociologist, policymakers as well as environmentalist $[39,40]$ If this activity continues, it has the potential to reduce fisheries in the future. Some low-value species like Acetes sp. have a low market price when sold after the first maturity. But the economic value increases when sold in dried form. As the fecundity rate of species like Acetes sp and Liza species are high which contribute in biggest biomass. Overall the livelihood of people is associated with this larvae collection activity [41]. No doubt, coastal aquaculture contributes significantly to rural employment and livelihood, but this is now hampered by ecological costs and negative social costs [42]. As discussed with fishers during group discussion, it is evident that fisher' are aware of the ecological loss but having no other option; they are compelled to engage in this tiresome activity.

The result indicates that the monetary loss of juveniles is high compared to the per ha production of shrimp in semi-intensive farm culture and the profit received from it. The ecological cost is often neglected. Simultaneously, the larvae activity is providing livelihood to the fish farmers. In addition, other people in the form of intermediaries are also involved in the post larvae trade. If ecological cost is more then what is the replacement to this activity so that the livelihood of people can be saved. 
To answer these questions, we must dig in the past to understand the situation when human evolved and started settling in Sundarbans. The people who came from near districts of West-Bengal as labourer to clear the forest and settled in Indian Part of sundarbans under Jamindars(landlord) became the Meendharas (fishers) after few decades[43]. As bonded labour, these people migrated to Sundarbans, and continued to live under the pressure of harsh climate adjusting with the nature. They fulfil their basic needs by hunting and fishing in the deep forest of Sundarbans. The government's interventions in the form of social and political law prohibited them to reach their livelihood and created a vicious cycle of poverty. This also reveals a series of political and social law that shaped the socio-economic condition of these labours now considered as fisherman. Resource-poor fishers, livelihood diversification is a strategy to cope with the uncertainties and in-adequateness of fisheries as a profession. [38]

\section{Conclusions}

The study concluded that P.monodon definitely helped in securing livelihood of local people in coastal Sundarbans. However, more social and ecological risks are involved. From a social context, the risk of working in critical environment particularly, threat from wild crocodile and skin diseases due to long water exposures during seed collection. From an ecological context, the loss of juveniles can impact the food chain and has the potential to impact fisheries in the long run. There is a conflict between livelihood, economic gain and environmental conservation. The economic gain from shrimp farming is at the cost of ecological damage, livelihood and the risk associated with it. Therefore, some issues need to be further investigated in terms of social justice and effective conservation. The conflict between livelihood and conservation will not be solved unless we provide alternative livelihood to the residents. The government should make provision to explore various livelihood opportunities which would not only provide economic security but also strengthen the social structure of the whole community by following principles of sustainable development. Another important issue is the creation of buffer zones and protected area, the subsequent forest and fishing regulations after creation of protected area hampers the livelihood option of local people.The creation of buffer zones and protected area prohibited the accessibility of fishing which impacted their livelihood. Bhattacharya and Sarkar,2003 suggested for identification of potential breeding grounds for tiger prawns and to make laws prohibiting fishing in those areas which will focus again upon implementation may deprive the local inhabitants of their livelihood. The fisheries resources and socio-economic database of fishers in Indian Sundarbans need to be re-assessed. There should be more coordination between different organization in terms of reaching out to people. Policy guidelines and management action plans should be made available in local language. The fishing community should be involved during decision making process and implementation of conservation project to ensure effective conservation.

Author Contributions: A.E.conceptualized the research idea. A.E. and A.P. designed and collected data. S.A.M and S.K.M. contributed in laboratory fish identification and methodology for biomass calculation of fish species. S.K.M. and S.K. contributed in providing secondary literature on length-weight relationship and mortality of individual fish species. D.B. assisted in field level identification of fish. A.E. drafted the manuscript. A.E., A.P. and B.K.D. revised and edited the paper.

Funding: The research was supported by Institute research fund from Indian council of Agricultural Research, project no. AES/ER/12/04/02

Acknowledgments: The authors would like to express their gratitude to all fishers and associated groups for the time and data and information provided for this paper.

Conflicts of Interest: The authors declare no conflict of interest 
Table A1. Sampling details for P.Monodon larvae collection

\begin{tabular}{llllll}
\hline S.No. & Month & P.monodon collected per day/boat & No. of Sample & Average Fishing Hours & No.of fishing days \\
\hline 1 & February & 550 & 8 & 6 & 14 \\
2 & March & 1600 & 8 & 6 & 20 \\
3 & April & 3250 & 8 & 6 & 20 \\
4 & May & 3750 & 4 & 8 & 25 \\
5 & June & 2250 & 4 & 8 & 30 \\
6 & July & 1250 & 4 & 8 & 30 \\
7 & August & 700 & 4 & 8 & 30 \\
\hline
\end{tabular}

Table A2. Length and weight relationship of species found in by-catch

\begin{tabular}{|c|c|c|c|c|c|c|}
\hline Species & $\operatorname{Lm}(\mathrm{cm})$ & $\mathbf{a}$ & b & References & $\mathbf{K}$ & References \\
\hline Charybdis rostrata & 7 & 0.14 & 3.078 & Dineshbabu [46] & 0.88 & Islam et al. [47] \\
\hline Coilia dussumieri & 16.25 & 0.00383 & 2.801 & Mohan Joseph and Jayaprakash [48], Amin and Zafar [49] & 0.8 & Fernandez and Devaraj [50] \\
\hline Eleotris senegalensis & 5.7 & 0.009 & 3.015 & Pezold and Cage [52] & 0.36 & Hashemi et al. [53] \\
\hline Eleutheronema tetradactylum & 28.5 & 0.016 & 2.961 & Abdul Samad [54] & 0.18 & Nabi [55] \\
\hline Escualosa thoracata & 8.2 & 0.0216 & 2.57 & Raje et al. [56] & 1.4 & Nabi [55] \\
\hline Exopalaemon styliferus & 6.3 & 0.006168 & 2.95 & Leung [57] & & Froese and Pauly [44] \\
\hline Gudusia chapra & 8 & 0.008597 & 2.8576 & Mondal and Kaviraj [61], Vinci et al. [62] & 0.25 & Afroz et al. [63] \\
\hline Harpadon nehereus & 21.45 & 0.00243 & 3.051 & Ghosh et al. [64?] & 0.519 & Balli et al. [65] \\
\hline Lepidocephalus guntea & 4.5 & 0.0029331 & 3.48 & Chakravarty et al. [66] & 0.7 & Sawusdee [67] \\
\hline Lepturacanthus savala & 38 & 0.000361 & 3.18 & Pakhmode et al. [68] & 0.75 & Ashraful [69] \\
\hline Lepturacanthus savala & 38 & 0.000361 & 3.18 & Pakhmode et al. [68] & 0.75 & Ashraful [69] \\
\hline Liza sp & 23.79 & 0.0055 & 3.1938 & Renjini and Bijoy Nandan [70] & 0.25 & Mitra and Mandal [71] \\
\hline Macrobrachium malcolmsonii & 7.5 & 0.005 & 3.33 & Venkataswamy et al. [72] & 0.2184 & Jenkataswamy et al. [72] \\
\hline Nandus nandus & 5 & 0.0192 & 2.95 & Hossain et al. [80], Parameswaran et al. [81] & 0.7 & Froese and Pauly [44] \\
\hline Odontamblyopus rubicundus & 5.4 & 0.00933 & 3.06 & Kader et al. [82] & 0.82 & Ullah et al. [83] \\
\hline Otolithoides pama & 110.5 & 0.0123 & 3.03 & Froese and Pauly [44] & 0.19 & Froese and Pauly [44] \\
\hline Parapenaeopsis sculptilis & 9.3 & 0.0037 & 3.26 & Fatima [84] & 1.25 & Mustafa [59] \\
\hline Parastromateus niger & 30 & 0.0138 & 2.54 & Pati [85] & 0.59 & Mustafa [59] \\
\hline Periophthalmus sp & 5 & 0.0164851 & 2.522 & Froese and Pauly [44] & 0.51 & Rao et al. [86] \\
\hline Photopectoralis bindus & 8 & 0.044 & 2.52 & Abraham et al. [74? ]Murty (1988) & 0.58 & Murty [87] \\
\hline Platycephalus indicus & 40 & 0.005 & 3.05 & Froese and Pauly [44] & 0.2313 & Jian-Dong [88] \\
\hline Polynemus paradiseus & 16 & 0.004127 & 3.1203 & Gupta [89]Mitra (2001) & 0.48 & Froese and Pauly [44] \\
\hline Pseudapocryptes elongatus & 15.4 & 0.0164 & 2.81 & Froese and Pauly [44] & 0.65 & Etim et al. [90] \\
\hline Scatophagus argus & 14 & 0.0377 & 2.922 & Shao et al. [91], Letourneur et al. [92] & 0.47 & Froese and Pauly [44] \\
\hline Scylla serrata & 12.4 & 0.00002 & 3.48 & Rezaie-Atagholipour et al. [93] & 0.28 & Dineshbabu [46] \\
\hline $\begin{array}{l}\text { Sepia sp. } \\
\text { (Dorsal mantle length) }\end{array}$ & 8.6 & 0.4067 & 2.5164 & Al-Marzouqi et al. [94] & 0.49 & Sukumaran [95] \\
\hline
\end{tabular}




\section{Appendix A Tables}

\section{References}

1. Mandal, B.; Mukherjee, A.; Banerjee, S. A review on the ichthyofaunal diversity in mangrove based estuary of Sundarbans. Reviews in fish biology and fisheries 2013, 23, 365-374.

2. Primavera, J. Mangroves as nurseries: shrimp populations in mangrove and non-mangrove habitats. Estuarine, Coastal and Shelf Science 1998, 46, 457-464.

3. MacNae, W. A general account of the fauna and flora of mangrove swamps and forests in the Indo-West-Pacific region. In Advances in marine biology; Elsevier, 1969; Vol. 6, pp. 73-270.

4. Chowdhury, A.; Naz, A.; Maiti, S.K. Health risk assessment of 'tiger prawn seed'collectors exposed to heavy metal pollution in the conserved mangrove forest of Indian Sundarbans: A socio-environmental perspective. Human and Ecological Risk Assessment: An International Journal 2017, 23, 203-224.

5. Aqua-Book, F. Shrimp aquaculture-global and Indian scenario, 2002.

6. Wood, J.; Brown, J.; MacLean, M.; Rajendran, I. Feeds for artisanal shrimp culture in India-their development and evaluation. Bay of Bengal Programme, Madras India 1992.

7. Sarkar, S.K.; Bhattacharya, A.K. Conservation of biodiversity of the coastal resources of Sundarbans, Northeast India: an integrated approach through environmental education. Marine pollution bulletin 2003, 47, 260-264.

8. Banerjee, B.; Singh, H.; others. The shrimp fry by-catch in West Bengal 1993.

9. Utpal, B.; Saha, S.; Mitra, P. Scenario of brackish water fin fish and shell fish seed collection in the Sunderbans, West Bengal. J. Inland Fish Soc., India 1993, 25, 44-50.

10. BOBP. Shrimp seed collectors of Bangladesh, 1990.

11. Ramesan, M.; Pravin, P.; Meenakumari, B. Non-selective fishing gears and sustainabilty issues in the hooghly-matlah estuary in west bengal, india 2009.

13. Hoq, M.E.; Islam, M.N.; Kamal, M.; Wahab, M.A. Abundance and seasonal distribution of Penaeus monodon postlarvae in the Sundarbans mangrove, Bangladesh. Hydrobiologia 2001, 457, 97-104.

14. Bhattacharya, A.; Sarkar, S.K. Impact of overexploitation of shellfish: Northeastern coast of India. Ambio 2003, pp. 70-75.

15. Iftekhar, M.; Islam, M. Degeneration of Bangladesh's Sundarbans mangroves: a management issue. International Forestry Review 2004, 6, 123-135.

16. Rahman, L.M. The Sundarbans: a unique wilderness of the world. In: McCool, Stephen F.; Cole, David N.; Borrie, William T.; O'Loughlin, Jennifer, comps. 2000. Wilderness science in a time of change conference-Volume 2: Wilderness within the context of larger systems; 1999 May 23-27; Missoula, MT. Proceedings RMRS-P-15-VOL-2. Ogden, UT: US Department of Agriculture, Forest Service, Rocky Mountain Research Station. p. 143-148, 2000, Vol. 15.

17. Chaudhuri, A.B.; Choudhury, A.; others. Mangroves of the Sundarbans. Volume 1: India.; International Union for Conservation of Nature and Natural Resources (IUCN), 1994.

18. Milliman, J.D.; Meade, R.H. World-wide delivery of river sediment to the oceans. The Journal of Geology 1983, 91, 1-21.

19. Morgan, J.P.; McINTIRE, W.G. Quaternary geology of the Bengal basin, East Pakistan and India. Geological Society of America Bulletin 1959, 70, 319-342.

20. Chakrabarti, P. Evolutionary history of the coastal quaternaries of the Bengal Plain, India. PROCEEDINGS-INDIAN NATIONAL SCIENCE ACADEMY PART A 1995, 61, 343-354.

21. Chaudhuri, A.; Mukherjee, S.; Homechaudhuri, S. Seasonal dynamics of fish assemblages in an intertidal mudflat of Indian Sundarbans. Scientia Marina 2013, 77, 301-311.

22. Bann, C.; others. Economic analysis of alternative mangrove management strategies in Koh Kong Province, Cambodia. EEPSEA research report series/IDRC. Regional Office for Southeast and East Asia, Economy and Environment Program for Southeast Asia 1997.

23. Sathirathai, S.; Barbier, E.B. Valuing mangrove conservation in southern Thailand. Contemporary Economic Policy 2001, 19, 109-122. 
24. Pargiter, F.E. A revenue history of the Sundarbans, from 1765 to 1870; Supt., Govt. Print., Bengal Govt. Press, 1934.

25. HDRCC, G. District Human Development Report North 24 Parganas. Kolkata: Development and Planning Department, Government of West Bengal 2010.

26. Danda, A.; Sriskanthan, G.; Ghosh, A.; Bandopadhyay, J.; Hazra, S. Indian Sundarbans Delta: A Vision, New Delhi: World Wide Fund for Nature-India, 2011.

27. Ghosh, A.; Schmidt, S.; Fickert, T.; Nüsser, M. The Indian Sundarban mangrove forests: history, utilization, conservation strategies and local perception. Diversity 2015, 7, 149-169.

28. Ghosh, P. Conservation and conflicts in the Sundarban biosphere reserve, India. Geographical Review 2015, 105, 429-440.

29. Mallick, R. Refugee resettlement in forest reserves: West Bengal policy reversal and the Marichjhapi massacre. The Journal of Asian Studies 1999, 58, 104-125.

30. Jalais, A. Dwelling on Morichjhanpi: When tigers became'citizens', refugees' tiger-food'. Economic and Political Weekly 2005, pp. 1757-1762.

31. Das, C.S.; Jana, R. Human-crocodile conflict in the Indian Sundarban: an analysis of spatio-temporal incidences in relation to people's livelihood. Oryx 2018, 52, 661-668.

32. Patel, V.; Rajagopalan, R. Fishing community issues in the Sundarban Tiger Reserve (STR). A Report for Workshop prepared by ICSF, Chennai, 2008.

33. Chacraverti, S. The Sundarbans fishers coping in an overly stressed mangrove estuary; International Collective in Support of Fishworkers, 2014.

34. Uptal, B.; Mitra, A. Impact of Lunar periodicity on availability of fin and shellfish seed with special reference to Penaeus monodon in the estuarine systems of Sunderbans, West Bengal. Int. J. of Research in Biosciences 2013, 2, 63-74.

35. Goswami, S.; Goswami, U. Lunar, diel and tidal variabilityin penaeid prawn larval abundance in the Mandovi estuary, Goa 1992.

36. Pauly, D. On the interrelationships between natural mortality, growth parameters, and mean environmental temperature in 175 fish stocks. ICES journal of Marine Science 1980, 39, 175-192.

37. Ricker, W.E. Computation and interpretation of biological statistics of fish populations; Vol. 191, Department of the Environment, Fisheries and Marine Service Ottawa, 1975.

38. Pandit, A.; Ekka, A.; Das, B.; Samanta, S.; Chakraborty, L.; Raman, R.K. Fishers' livelihood diversification in Bhagirathi-Hooghly stretch of Ganga River in India. Current Science 2019, 116, 1748.

39. Gaihiamngam, K.; Chakraborty, S.; Deshmukhe, G.; Jaiswar, A.; Devi, H.; Suman, K.; Sreekanth, G.; others. Assessment of economic impact of juvenile fishing of sciaenids along Mumbai Coast, India. Indian Journal of Geo-Marine Sciences 2013, 42, 617-621.

40. Kamei, G.; Chakraborty, S.; Deshmukhe, G.; Jaiswar, A.; Devi, H.M.; Kumari, S.; Sreekanth, G. Assessment of economic impact of juvenile fishing of sciaenids along Mumbai Coast, India 2013.

41. Ahamed, F.; Hossain, M.Y.; Fulanda, B.; Ahmed, Z.F.; Ohtomi, J. Indiscriminate exploitation of wild prawn postlarvae in the coastal region of Bangladesh: A threat to the fisheries resources, community livelihoods and biodiversity. Ocean $\mathcal{E}$ coastal management 2012, 66, 56-62.

42. Azad, A.K.; Jensen, K.R.; Lin, C.K. Coastal aquaculture development in Bangladesh: unsustainable and sustainable experiences. Environmental management 2009, 44, 800-809.

43. Ray, R.; Chakraborty, I.; Bhattacharyya, N. A Study among Some "Meendharas" of Sunderbans, West Bengal. The Anthropologist 2002, 4, 83-89.

44. Froese, R.; Pauly, D. FishBase. World Wide Web electronic publication, version (10/2017) 2017.

45. Chakraborty, S.K.; Deshmukh, V.D.; Khan, M.Z.; Vidyasagar, K.; Raje, S.G. Estimates of growth, mortality, recruitment pattern and maximum sustainable yield of important fishery resources of Maharashtra coast 1997.

46. Dineshbabu, A. Biology and exploitation of the crucifix crab, Charybdis (Charybdis) feriata (Linnaeus, 1758)(Brachyura: Portunidae) from Karnataka coast, India. Indian Journal of Fisheries 2011, 58, $25-29$.

47. Islam, M.S.; Khan, M.; Quayum, S.; Sada, M.; Chowdhury, Z. The estuarine set bagnet fishery. Studies of Interactive Marine Fisheries of Bangladesh. Bay of Bengal Program 1993, pp. 19-50.

48. Mohan Joseph, M.; Jayaprakash, A. Status of exploited marine fishery resources of India, 2003. 
49. Amin, S.N.; Zafar, M. Studies on age, growth and virtual population analysis of Coilia dussumieri from the neritic water of Bangladesh. J. Biol. Sci 2004, 4, 342-344.

50. Fernandez, I.; Devaraj, M. Stock assessment and dynamics of Coilia dussumieri (Engraulidae) resource in the Indian Exclusive Economic Zone along the Northwestern Coast of India. Asian Fish. Sci 1988, 1, 157-64.

51. Manojkumar, P. Fishery, biology and stock assessment of Cynoglossus macrostomus (Norman) off Malabar coast. Indian Journal of Fisheries 2006, 53, 441-447.

52. Pezold, F.; Cage, B. A review of the spinycheek sleepers, genus Eleotris (Teleostei: Eleotridae), of the Western Hemisphere, with comparison to the West African species. Tulane Stud. Zool. Bot 2002, 31, $19-63$. 53. Hashemi, S.; Taghavimotlagh, S.; Ghorbani, R.; Hedayati, A. Population parameters and length-weight relationship of deep flounder (Pseudorhombus elevatus) in northwest of Persian Gulf (Khuzestan coastal waters, Iran). International Journal of MArine Science and Engineering 2013, 3, 1-6.

54. Abdul Samad, G. Some biological aspects of threadfin, Eleutheronema tetradactylum Shaw, from Musi Estuary, South Sumatra, Indonesia. Proceedings of the Regional Introductory Training Course on Estuarine Research Calcutta 1987, pp. 1-16.

55. Nabi, M. Management of estuarine set bag net fisheries of Bangladesh: application of traditional Scientific method, local indigenous knowledge and sustainable livelihood approach. PhD thesis, Ph. D. thesis, Borneo Marine Research Institute, University Malaysia Sabah ..., 2007.

56. Raje, S.; Deshmukh, V.; Das, T. Fishery and biology of white sardine, Escualosa thoracata (Valenciennes) at Versova, Bombay. Journal of the Indian Fisheries Association 1994, 24, 51-62.

57. Leung, S. H. MILNE-EDWARDS (PALAEMONIDAE) IN A TRADITIONAL TIDAL SHRIMP POND AT THE MAIPO MARSHES NATURE RESERVE. Asian Marine Biology 1995, 11, 55-78.

58. Dholakia, A. Fisheries and aquatic resources of India; Daya Books, 2004.

59. Mustafa, M. Population dynamics of penaeid shrimps and demersal finfishes from trawl fishery in the Bay of Bengal and implication for the management. PhD thesis, Ph. D. thesis, Department of Zoology, University of Dhaka, Bangladesh, 1999.

60. Marquez, J. Age and size at sexual maturity of white goby (Glossogobius giuris) a common species of fish of Laguna de Bay, with notes on its food habits. Philippine Journal of Fisheries 1960, 8, 71-101.

61. Mondal, D.K.; Kaviraj, A. Feeding and reproductive biology of Indian shad Gudusia chapra in two floodplain lakes of India. Electronic Journal of Biology 2010, 6, 98-102.

62. Vinci, G.; Suresh, V.; Bandyopadhyaya, M. Biology of Gudusia chapra (Hamilton-Buchanan) from a floodplain wetland in West Bengal. Indian Journal of Fisheries 2005, 52, 73-79.

63. Afroz, T.; Nabi, M.; Mustafa, G. Age and growth of chapila, Gudusia chapra (Ham.) from Jahangirnagar University ponds. BANGLADESH JOURNAL OF ZOOLOGY 2000, 28, 49-54.

64. Ghosh, S.; Pillai, N.; Dhokia, H. Fishery and population dynamics of Harpadon nehereus (Ham.) off the Saurashtra coast. Indian Journal of Fisheries 2009, 56, 13-19.

65. Balli, J.J.; Chakraborty, S.; Jaiswar, A. Population dynamics of Bombay duck Harpadontidae nehereus (Ham. 1822)(Teleostomi/Harpadontidae) from Mumbai waters, India 2011.

66. Chakravarty, M.S.; Pavani, B.; Ganesh, P. Length-weight relationship of ribbon fishes: Trichiurus lepturus (Linnaeus, 1758) and Lepturacanthus savala (Cuvier, 1829) from Visakhapatnam coast. J Mar Biol Ass India 2012, 54, 99-101.

67. Sawusdee, A. Population dynamics of the Spotted Scat Scatophagus argus (Linnaeus, 1766) in Pak Panang Bay, Nakhon Si Thammarat, Thailand. Walailak Journal of Science and Technology (WJST) 2010, 7, 23-31.

68. Pakhmode, P.K.; Mohite, S.A.; Naik, S.D.; Mohite, A.S. Length-frequency analysis and length-weightrelationship of ribbon fish Lepturacanthus savala (Cuvier1829) off Ratnagiri coast Maharashtra. Int. J. Fish. aquat. Stud 2013, 1, 25-30.

69. Ashraful, H. Population dynamics of five commercially important marine fishes in north-eastern part of the Bay of Bengal. Institute of Marine Sciences, University of Chittagong, Chittagong, Bangladesh. PhD thesis, Master's Thesis, 1998.

70. Renjini, P.; Bijoy Nandan, S. Length-weight relationship, condition factor and morphometry of gold spot mullet Liza parsia (Hamilton, 1822) from Cochin estuary 2011.

71. Mitra, P.; Mandal, S. Population dynamics and stock assessment of Liza Parsia of Hooghly-Malta estuarine system. J.Inland Fish Soc. India 1997, 29, 11-16. 
72. Venkataswamy, M.; John, K.R.; Rahman, M.K. Transportation of Macrobrachium malcolmsonii juveniles and broodstock. Freshwater prawns faculty of fisheries. Thrissure, India: Kerala Agricultural University 1992, pp. 148-51.

73. Rajyalakshmi, T. OBSERVATIONS ON THE BIOLOGY AND FISHERY OF METAPENAEUS BREVICORNIS (M. EDW.> IN THE HOOGHLY ESTUARINE SYSTEM. Indian Journal of Fisheries 1961, 8, 383-402.

74. Abraham, K.; Joshi, K.; Murty, V.S. Taxonomy of the fishes of the family Leiognathidae (Pisces, Teleostei) from the West coast of India. Zootaxa 2011, 2886, 1-18.

75. Dineshbabu, A. Fishery and some biological aspects of penaeid shrimps along Saurashtra region. Journal of the Marine Biological Association of India 2003, 45, 195-207.

76. Dinh, T.; Moreau, J.; Van, M.; Phuong, N.; Toan, V. Population dynamics of shrimps in littoral marine waters of the Mekong Delta, South of Viet Nam. Pakistan Journal of Biological Sciences 2010, 13, 683-690.

77. Pantulu, V.R. Determination of age and growth of Mystus gulio (Ham.) by the use of pectoral spines, with observations on its biology and fishery in the Hooghly estuary. Proc. nat. Inst. Sci. India, 1961, Vol. 27, pp. 198-225.

78. Begum, M.; Islam, M.; Pal, H.; Alam, M. Reproductive characteristics of Liza parsia (Ham.) inhabiting southwest coast of Bangladesh. Journal of the Bangladesh Agricultural University 2010, 8, 173-178.

79. De Graaf, G. The flood pulse and growth of floodplain fish in Bangladesh. Fisheries Management and Ecology 2003, 10, 241-247.

80. Hossain, M.Y.; Jewel, M.A.S.; Rahman, M.; Haque, A.; Elbaghdady, H.A.M.; Ohtomi, J.; others. Life-history traits of the freshwater garfish Xenentodon cancila (Hamilton 1822)(Belonidae) in the Ganges river, Northwestern Bangladesh. Sains Malaysiana 2013, 42, 1207-1218.

81. Parameswaran, S.; Radhakrishnan, S.; Selvaraj, C. Some observations on the biology and life-history ofNandus nandus (Hamilton). Proceedings of the Indian Academy of Sciences-Section B. Springer, 1971, Vol. 73, pp. 132-147.

82. Kader, M.; Bhuiyan, A.; Manzur, A.; Khuda, I. The reproductive biology of Gobioides rubicundus (Ham. Buch.) in the Karnaphuli River estuary, Chittagong. Indian Journal of Fisheries 1988, 35, 239-250.

83. Ullah, M.H.; Rashed-Un-Nabi, M.; Al-Mamun, M.A. Trophic model of the coastal ecosystem of the Bay of Bengal using mass balance Ecopath model. Ecological Modelling 2012, 225, 82-94.

84. Fatima, M. Study on Length-frequency and Length-weight Relationship of Penaeus japonicus and Parapenaeopsis sculptilis. Journal of Biological Sciences 2001, 1, 171-172.

85. Pati, S. Observations on the length-weight relationship of pomfrets from the Bay of Bengal. Mahasagar 1981, 14, 83-85.

86. Rao, G.S.; Thangaraj Subramanian, V.; Rajamani, M.; Sampson Manickam, P.; Maheswarudu, G. Stock assessment of Penaeus spp. off the east coast of India. Indian journal of Fisheries 1993, 40, 1-19.

87. Murty, V.S. Studies on the growth and population dynamics of silverbelly Leiognathus bindus (Valenciennes) in the trawling grounds off Kakinada. Indian Journal of Fisheries 1986, 33, 277-284.

88. Jian-Dong, Y.F.L.Z. STUDY ON AGE, GROWTE AND LIFE-HISTORY PATTERN OF (ELEOTRIS OXYCEPHALA TEMMINCK ET SCHLEGEL)[J]. Acta Ecologica Sinica 1993, 1.

89. Gupta, M.V. Observations on the fecundity of Polynemus paradiseus Linn. from the Hooghly estuarine system. Central Inland Fisheries Research Institute, Barrackpore, India 1968, pp. 120-149.

90. Etim, L.; Brey, T.; Arntz, W. A seminal study of the dynamics of a mudskipper (Periophthalmus papilio) population in the Cross River, Nigeria. Netherland Journal of aquatic ecology 1996, 30, 41-48.

91. Shao, Y.T.; Hwang, L.Y.; Lee, T.H. Histological observations of ovotestis in the spotted scat Scatophagus argus. Fisheries science 2004, 70, 716-718.

92. Letourneur, Y.; Kulbicki, M.; Labrosse, P. Length-weight relationship of fishes from coral reefs and lagoons of New Caledonia: an update. Naga, the ICLARM Quarterly 1998, 21, 39-46.

93. Rezaie-Atagholipour, M.; Naderloo, R.; Kamrani, E.; Savari, R.; others. Preliminary biological information of Scylla serrata (Forskål, 1775)(Brachyura, Portunidae) in the Persian Gulf and Gulf of Oman: a conservation priority. Crustaceana 2013, 86, 322-335.

94. Al-Marzouqi, A.; Jayabalan, N.; Al-Nahdi, A. Biology and stock assessment of the pharaoh cuttlefish, Sepia pharaonis Ehrenberg, 1831 from the Arabian Sea off Oman. Indian J. Fish 2009, 56, 231-239.

95. Sukumaran, K. Study on the fishery and biology of the mantis shrimp Oratosquilla nepa (latreille) of south kanara coast during 1979-83. Indian Journal of Fisheries 1987, 34, 292-305. 
484 96. Jhingran, A. Studies on the maturity and fecundity of the Gangetic anchovy, Setipinna phasa (Hamilton).

485 Indian Journal of Fisheries 1961, 8, 291-311.

486 97. Alagaraja, K.; Jhingran, A. Application of Von Bertalanffy's growth model to Setipinna phasa (Hamilton) 487 when growth is allometric. Aquaculture 1976, 9, 181-186.

488 98. Andamari, R.; Milton, D.; Zubaidi, T. Reproductive biology of five species of anchovies (Engraulidae) from 489 Bima Bay, Sumbawa, Nusa Tenggara. Indonesian Journal of Agricultural Science 2013, 3, $37-42$.

490 99. Abdurahiman, K.; Nayak, T.; Zacharia, P.; Mohamed, K. Length-weight relationship of commercially important marine fishes and shellfishes of the southern coast of Karnataka, India. NAGA, World Fish Centre $492 \quad$ Quarterly 2004, 27, 9-14.

493 100. Pillay, T. Biology of the hilsa, Hilsa ilisha (Hamilton) of the river Hooghly. Indian Journal of Fisheries 1958, $494 \quad 5,201-257$.

495 101. Aydın, M. Growth, reproduction and diet of pufferfish (Lagocephalus sceleratus Gmelin, 1789) from Turkey's Mediterranean Sea coast. Turkish Journal of Fisheries and Aquatic Sciences 2011, 11, 569-576. 